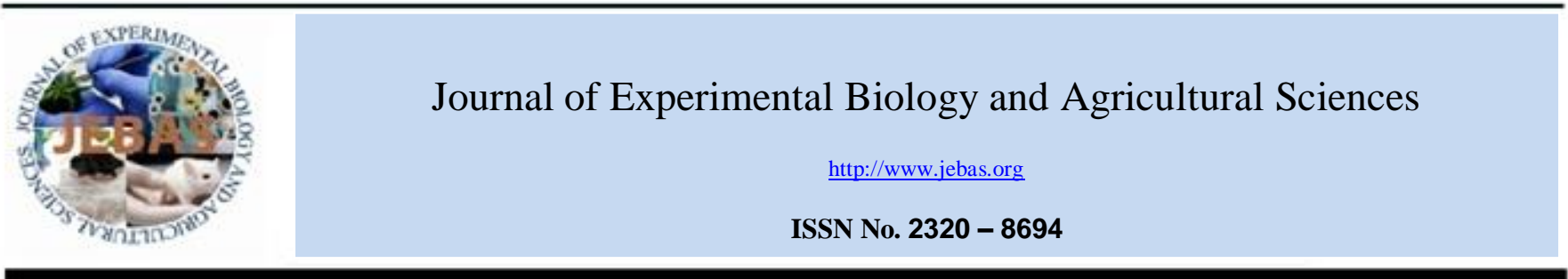

\title{
EFFECT OF FEEDING MOLASSES BASED MULTI-NUTRIENT LIQUID SUPPLEMENT ON EARLY LACTATION PERFORMANCE, INTAKE AND NUTRIENT DIGESTIBILITY IN CROSSBRED COWS
}

\author{
Anuraj KS ${ }^{1}$, Putan Singh ${ }^{2 *}$, AK Verma ${ }^{3}$, VB Chaturvedi ${ }^{2}$, GK Gaur ${ }^{2}$
}

${ }^{1}$ Ph.D. Scholar, Animal Nutrition Division, ICAR-IVRI, Izatnagar-243122

${ }^{2}$ Principal Scientist, Animal Nutrition Division, ICAR-IVRI, Izatnagar-243122

${ }^{3}$ Head \& Principal Scientist, Animal Nutrition Division, ICAR-IVRI, Izatnagar-243122

Received - August 05, 2017; Revision - August 25, 2017; Accepted - September 06, 2017

Available Online - September 10, 2017

DOI: http://dx.doi.org/10.18006/2017.5(4).545.549

\section{KEYWORDS}

Dairy cow

Nutrient digestibility

Lactation performance

Molasses based multi-nutrient liquid

\section{ABSTRACT}

An experiment was conducted to assess the lactation performance and nutrient utilization of early lactating crossbred dairy cows fed with molasses based multi-nutrient liquid supplement (MMLS). A total of eighteen early lactating cows were divided into three groups (T1, T2 and T3) with six cows in each group following completely randomized design on the basis of body weight and milk production. Cows were fed concentrate mixture, green fodder and wheat straw to meet the nutrient requirement. The control group (T1) was fed basal diet without MMLS, whereas treatment groups (T2 and T3) were fed MMLS replacing 15 and 30\% concentrate mixture, respectively. Feeding of MMLS did not show any significant change in average intake of dry matter (DM), organic matter $(\mathrm{OM})$, crude protein $(\mathrm{CP})$ and neutral detergent fiber (NDF) compared to control group. The ether extract (EE) intake of MMLS fed groups ( $\mathrm{T} 2$ and $\mathrm{T} 3$ ) was lower $(\mathrm{P}<0.05)$ due to high $\mathrm{EE}$ content of concentrate mixture compared to MMLS. The acid detergent fiber $(\mathrm{ADF})$ intake of $\mathrm{T} 3$ was higher $(\mathrm{P}<0.05)$ due to higher wheat straw intake. The digestibility of DM, OM, CP, EE, NDF and ADF were noted unchanged among all the three groups. The MMLS feeding did not show any significant change in milk yield of the animals when compared to control group. The findings of current study suggested that there was no adverse effect on intake and digestibility of nutrients and lactation performance due to feeding of MMLS to dairy cows while replacing up to $30 \%$ of concentrate mixture in diet.
* Corresponding author

E-mail: putan60@gmail.com (Putan Singh)

Peer review under responsibility of Journal of Experimental Biology and Agricultural Sciences.

Production and Hosting by Horizon Publisher India [HPI] (http://www.horizonpublisherindia.in/).

All rights reserved.
All the article published by Journal of Experimental Biology and Agricultural Sciences is licensed under a Creative Commons Attribution-NonCommercial 4.0 International License Based on a work at www.jebas.org.

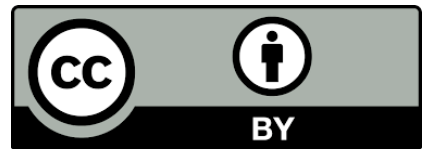




\section{Introduction}

In India, dairy farming has become one of the major sources of income, providing employment for a significant number of rural families. India is not only the largest milk producer, but also is one of the fastest growing and lowest cost milk producers in the world. Chronic shortage of good quality feeds and fodders and dependency on crop residues as feed resources leads to lower productivity dairy animals in the country (Ojha, 2013). Deficient supply of dietary protein results in low rates of reproduction and poor production as well as increased susceptibility to various diseases (Bindari et al., 2013). Availability of oil cakes as a protein supplement in developing countries is very poor and at a very high price, this has led to use non-protein nitrogen source as urea, to compensate the nitrogen deficiency of fibrous feeds (Dutta \& Sharma, 2004). Thus, enhancing intake, digestibility and availability of nutrients from poor quality roughages are only possible through optimization of rumen fermentation (Saadullah et al., 1981). Urea in combination with a readily available energy source (such as molasses) was found promising when either fed with or sprayed over poor quality roughages, or used as a ureamolasses supplement (Preston \& Leng, 1987; Dass et al., 1996; Mehra et al., 1998, Maneerat et al., 2015). Molasses based liquid supplements have been used as a source of non-protein nitrogen, energy, minerals and vitamins for dairy cows. Liquid feed supplements offer an alternative delivery vehicle for supplemental fat, protein, and rumen-fermentable carbohydrates, minerals and vitamins in rations for lactating dairy cows (Ankita et al., 2016). Molasses based liquid feed supplements can be used as a source to provide non-protein nitrogen, energy, minerals and vitamins for dairy cows. However, little research has been done on molasses based liquid supplements for improving the performance of dairy cattle. Therefore, an attempt was made to evaluate the effect of feeding molasses based multi-nutrient liquid supplement (MMLS) on lactation performance and nutrient utilization in crossbred dairy cows in early stage of lactation.

\section{Materials and Methods}

\subsection{Site, Animals and Diets}

The experiment was conducted on a total of 18 multiparous crossbred dairy cows in the early stage of lactation at Cattle and Buffalo Farm, Indian Veterinary Research Institute, Izatnagar. All the animals were fed to meet out nutrient requirement as per ICAR (1998). The dairy cows were distributed into three groups (T1, T2 and T3) of six cows in each group using a completely randomized design on the basis of body weight and milk yield. The cows in control group (T1) were fed basal diet of green maize (5 $\mathrm{kg} \mathrm{DM})$ and ad libitum wheat straw. Along with green maize and wheat straw, the required amount of concentrate mixture to meet their nutrient requirements for maintenance and milk production were also provided in $\mathrm{T} 1$. In group $\mathrm{T} 2$, the concentrate mixture was replaced by MMLS by $15 \%$ based on crude protein whereas, in treatment group $\mathrm{T} 3$, the concentrate mixture was replaced by MMLS by $30 \%$. The composition of concentrate mixture and MMLS is given in Table 1. Throughout the experimental period of 100 days, clean and fresh drinking water was provided. Animals were maintained under uniform management and hygienic conditions.

\subsection{Data recording and sampling}

Digestion trial on all the animals was conducted after 90 days of feeding. The feed offered and the residue left were weighed after 24 hours of feeding daily. Body weight of each animal was recorded at monthly intervals. The chemical composition of

Table 1 Composition of concentrate mixture and MMLS

\begin{tabular}{|cccc|}
\hline CONCENTRATE MIXTURE & & & MMLS \\
Ingredient & $\%$ & Ingredient & Parts \\
\hline Maize & 35 & Molasses $(\mathrm{kg})$ & 94 \\
\hline Soybean meal & 17 & Urea $(\mathrm{kg})$ & 10 \\
\hline Mustard cake & 5 & Deoiled Mahua cake(kg) & 10 \\
\hline Wheat bran & 40 & Guar meal $(\mathrm{kg})$ & 1 \\
\hline Mineral mixture & 2 & Common salt $(\mathrm{kg})$ & 4 \\
\hline Salt & 1 & Mineral mixture $(\mathrm{kg})$ & 2 \\
\hline
\end{tabular}

Journal of Experimental Biology and Agriculture Science http://www.jebas.org 
Table 2 Chemical composition of concentrate mixture, MMLS, wheat straw and green fodder (\% DM basis)

\begin{tabular}{|cccccc|}
\hline Attributes & $\begin{array}{c}\text { Concentrate } \\
\text { Mixture }\end{array}$ & MMLS & Wheat Straw & Green Maize \\
\hline Organic Matter (OM) & 93.76 & 87.84 & 91.06 & 91.58 \\
\hline Crude Protein (CP) & 18.4 & 30.1 & 2.98 & 9.46 \\
\hline Ether Extract (EE) & 2.18 & 1.31 & 7.28 & 7.06 & 66.85 \\
\hline Neutral Detergent Fiber (NDF) & 32.43 & 7.87 & 75.31 & 40.12 \\
\hline Acid Detergent Fiber (NDF) & 11.26 & 6.26 & 57.48 & 8.94 & \\
\hline Total Ash (TA) & 6.24 & 12.16 & 8.42 \\
\hline
\end{tabular}

concentrate mixture, MMLS, green maize and wheat straw is given in Table 2. During digestion trial of six days duration, fecal samples were collected after $24 \mathrm{~h}$ of feeding. The samples of feed offered, residue and feces were analyzed according to standard procedures (AOAC, 2000) to calculate nutrient digestibility. Daily milk yield of all the animals was recorded morning and evening throughout the experimental period.

\subsection{Statistical analysis}

The data was analyzed using SPSS Version 16.0, SPSS Inc,
Chicago, USA. General Linear model ANOVA was used to assess the intergroup variation. Statistical significance of the results was calculated at $\mathrm{P}<0.05$.

\section{Results and Discussion}

\subsection{Intake and digestibility of various nutrients}

The nutrition plan of dairy cows during digestion trial is presented in Table 3. The mean body weight of animals during digestion trial was noted unchanged among the three groups. Daily intake

Table 3 Effect of MMLS feeding on nutrient intake and digestibility of dairy cows

\begin{tabular}{|c|c|c|c|c|c|}
\hline \multirow{2}{*}{ Attributes } & \multicolumn{3}{|c|}{ Groups } & \multirow{2}{*}{ SEM } & \multirow{2}{*}{$\mathrm{P}$ value } \\
\hline & $\mathrm{T}-1$ & $\mathrm{~T}-2$ & $\mathrm{~T}-3$ & & \\
\hline \multicolumn{6}{|c|}{ Intake $(\mathrm{kg} / \mathrm{d})$} \\
\hline DM & 11.94 & 11.53 & 11.98 & 0.10 & 0.117 \\
\hline $\mathrm{OM}$ & 11.04 & 10.63 & 11.00 & 0.09 & 0.115 \\
\hline $\mathrm{CP}$ & 1.51 & 1.51 & 1.55 & 0.01 & 0.272 \\
\hline $\mathrm{EE}(\mathrm{g} / \mathrm{d})$ & $242.66^{\mathrm{a}}$ & $229.95^{\mathrm{b}}$ & $229.08^{b}$ & 1.84 & 0.003 \\
\hline NDF & 6.31 & 6.01 & 6.32 & 0.06 & 0.061 \\
\hline $\mathrm{ADF}$ & $3.51^{\mathrm{a}}$ & $3.40^{\mathrm{a}}$ & $3.74^{\mathrm{b}}$ & 0.04 & 0.003 \\
\hline \multicolumn{6}{|c|}{ Apparent digestibility (\%) } \\
\hline DM & 71.79 & 71.29 & 70.94 & 0.57 & 0.835 \\
\hline OM & 74.53 & 73.99 & 73.57 & 0.51 & 0.754 \\
\hline $\mathrm{CP}$ & 72.15 & 72.48 & 71.80 & 0.55 & 0.881 \\
\hline $\mathrm{EE}$ & 77.27 & 76.37 & 75.06 & 0.48 & 0.178 \\
\hline NDF & 66.66 & 65.63 & 65.69 & 0.69 & 0.804 \\
\hline $\mathrm{ADF}$ & 57.01 & 56.46 & 58.53 & 0.91 & 0.642 \\
\hline \multicolumn{6}{|c|}{ Plane of nutrition ( $\mathrm{kg} /$ day) } \\
\hline DOMI & 8.24 & 7.86 & 8.10 & 0.09 & 0.203 \\
\hline DCPI & 1.09 & 1.09 & 1.12 & 0.01 & 0.677 \\
\hline TDNI & 8.37 & 8.08 & 8.31 & 0.09 & 0.195 \\
\hline
\end{tabular}

DOMI: digestible organic matter intake; DCPI: digestible crude protein intake; TDNI: total digestible nutrient intake

${ }^{\mathrm{ab}}$ Mean values with different superscripts within a row differs significantly $(\mathrm{P}<0.05)$ 
$(\mathrm{kg} / \mathrm{d})$ of DM, OM, CP, NDF, DCP and total digestible nutrients (TDN) by crossbred dairy cows did not differ significantly $(\mathrm{P}>0.05)$ among different treatment groups. However, the ether extract intake was significantly lower $(\mathrm{P}<0.05)$ in the treatment groups as compared to control group. The reduction of EE intake might be due to higher ether extract content of concentrate mixture as compared to MMLS as evident from chemical composition. Also, the ADF intake was significantly higher $(\mathrm{P}<0.05)$ in the $\mathrm{T} 3$ when compared to $\mathrm{T} 1$ and $\mathrm{T} 2$. This might be due to the higher intake of wheat straw by the animals in T3 (Table 3). The results indicated that the mean DM intake did not vary significantly among three groups. Results of this study corroborated with those of Hosamani et al. (1998) and Sahoo et al. (2004) who reported that there was a non-significant increase in intake of DM and TDN due to urea molasses mineral supplement feeding in buffaloes. Moreover, Mohini \& Singh (2010) also observed similar findings in DM, CP, DCP and TDN intake in crossbred dairy cows fed urea molasses mineral block replacing $35 \%$ of concentrate mixture and those fed standard ration without urea molasses mineral block.

The digestibility of various nutrients is presented in Table 3. In the present study, feeding of MMLS did not affect the digestibility of DM, OM, CP, EE, NDF and ADF in treatment groups. Mohini \& Singh (2010) also observed non-significant changes in digestibility of $\mathrm{DM}, \mathrm{OM}$ and $\mathrm{CP}$ in crossbred dairy cows fed urea molasses mineral block replacing $35 \%$ of concentrate mixture and fed standard ration without urea molasses mineral block. Similar results were also observed by Singh \& Kishan (1994) when buffaloes were fed urea either mixed with concentrate mixture or wheat straw or as urea-ammonia treated straw in order to meet out $30 \%$ of the protein requirement through urea. In another study regarding digestibility of DM, OM, CP, Crude Fibre (CF) and Nitrogen Free Extract (NFE) conducted by Chauhan et al. (1995), the result showed non-significant difference in treatment groups in comparison to control when $20 \%$ concentrate mixture was replaced by feeding urea molasses mineral block at $600-700 \mathrm{~g}$ to buffalo heifers along with wheat straw and berseem fodder.

\subsection{Lactation performance}

The fortnightly changes in milk yield are given in Table 4. The results indicated that feed supplementation of MMLS with the replacement of $15 \%$ and $30 \%$ concentrate mixture dairy cows did not have any adverse effect on milk yield. The non-significance in the milk yield between the groups showed that the MMLS provided enough nutrients to cover up reduced intake of concentrate mixture in the MMLS fed groups. The results of current study are in line with Mohini \& Singh (2010) who observed non-significant difference in milk yield in crossbred dairy cows fed urea molasses mineral block replacing 35\% of concentrate mixture. The milk yield was non-significant among the three groups which indicated that the MMLS provided enough nutrients to compensate the reduced intake of concentrate mixture in treatment groups T2 and T3. In contrary to this study, Akter et al. (2004) reported that supplementation of urea molasses mineral block to dairy cows receiving straw based diets improve the milk production up to 2.86 to $4.43 \mathrm{~L} / \mathrm{d}(\mathrm{P}<0.01)$. The increase in intakes of energy and nitrogen resulted in increase in milk yield. Wanapat et al. (1999) observed that significant increase in milk yield of lactating dairy cows due to feeding of urea molasses mineral block (UMMB). Plaizier et al. (1999) reported an increase in milk production by $4.5 \mathrm{~L} / \mathrm{d}$ on supplementation of urea molasses blocks to dairy cows which were fed a basal diet of ad libitum grass hay and maize bran. Ramesh et al. (2009) reported that feeding of UMMB improve the milk production in buffaloes and cows. The increase in milk production was due to the fact that UMMB was provided as a supplement along with the basal diet of concentrate mixture and other feeds offered to lactating animals. However, in the present study, we replace concentrate mixture with $15 \%$ and $30 \%$ MMLS on equal protein proportion, the treatment groups (T2 and $\mathrm{T} 3$ ) receive isonitrogenous and isocaloric diets, daily milk production in all the three groups was similar.

Table 4 Effect of MMLS feeding on milk yield $(\mathrm{kg})$ of dairy cows

\begin{tabular}{|c|c|c|c|c|c|}
\hline \multirow{2}{*}{$\begin{array}{c}\text { Fortnight } \\
\mathrm{s}\end{array}$} & \multicolumn{3}{|c|}{ Groups } & \multirow{2}{*}{ SEM } & \multirow{2}{*}{$P$ value } \\
\hline & $\mathrm{T}-1$ & $\mathrm{~T}-2$ & T-3 & & \\
\hline 1 & 8.83 & 9.04 & 9.10 & 0.29 & 0.931 \\
\hline 2 & 11.19 & 10.58 & 11.69 & 0.41 & 0.563 \\
\hline 3 & 12.97 & 12.21 & 13.06 & 0.34 & 0.553 \\
\hline 4 & 14.32 & 13.58 & 14.75 & 0.36 & 0.421 \\
\hline 5 & 14.81 & 14.41 & 15.02 & 0.38 & 0.818 \\
\hline 6 & 14.31 & 14.70 & 14.92 & 0.31 & 0.739 \\
\hline 7 & 13.67 & 14.17 & 13.42 & 0.30 & 0.603 \\
\hline Average & 12.87 & 12.67 & 13.13 & 0.31 & 0.84 \\
\hline
\end{tabular}

\section{Conclusion}

The results of present study concluded that $30 \%$ of concentrate mixture can be replaced with MMLS without any adverse effects on feed intake, digestibility of nutrients and milk production of crossbred cows in early lactation.

\section{Conflict of Interest}

Authors declare that there is no conflict of interests arising from this study. 


\section{References}

Akter Y, Akbar MA, Shahjalal M, Ahmed TU (2004) Effect of urea molasses multi-nutrient blocks supplementation of dairy cows fed rice straw and green grasses on milk yield, composition, live weight gain of cows and calves and feed intake. Pakistan Journal of Biological Sciences 7: 1523-1525.

Ankita Y, Verma AK, Singh P, Das A, Gaur GA (2016) Effects of replacement of concentrate mixture with a multi-nutrient nutrient supplement on performance of buffalo heifers. Indian Journal of Animal Sciences $86: 1036-1040$.

AOAC (2000) Official Methods of Analysis, 18th ed. Association of Official Analytical Chemists, Arlington, Virginia.

Bindari YR, Shrestha S, Shrestha N, Gaire TN (2013) Effects of nutrition of reproduction - A review. Advances in Applied Science Research 4 : 421-429.

Chauhan TR, Dahiya SS, Punia BS (1995) Effect of supplementing urea molasses block (UMB) containing partly degradable proteins on nutrient utilization in lactating buffaloes with oat silage as basal roughage. Buffalo Journal 11: 249-256.

Dass RS, Verma AK, Mehra UR (1996) Effect of feeding ureamolasses liquid diet on nutrient utilization, rumen fermentation pattern and blood profile in adult male buffaloes. Buffalo Journal 12: $11-22$.

Dutta N, Sharma K (2004) Replacement of wheat bran by rice polishings as an economic supplement to wheat straw diet for lactating buffaloes in northern plains of India. Animal Nutrition and Feed Technology 4: 113-120.

Hosamani SV, Mehra UR, Dass RS (1998) Effect of different planes of nutrition on urea molasses mineral block intake, nutrient utilization, rumen fermentation pattern and blood profile in Murrah buffaloes (Bubalus bubalis). Animal Feed Science and Technology 76: 117-128.

ICAR (1998) Nutrient Requirements of Animals- Cattle and Buffalo.

Maneerat W, Prasanpanich S, Tumwasorn S, Laudadio V, Tufarelli V (2015) Evaluating agro-industrial by-products as dietary roughage source on growth performance of fattening steers. Saudi Journal of Biological Sciences $22: 580-584$.

Mehra UR, Verma AK, Dass RS (1998) Effect of restricted and ad libitum feeding of urea molasses liquid diet (UMLD) on the performance of adult crossbred cattle. Asian-Australasian Journal of Animal Sciences 11: 30-34.

Mohini M, Singh GP (2010) Effect of supplementation of urea molasses mineral block (UMMB) on the milk yield and methane production in lactating cattle on different plane of nutrition. Indian Journal of Animal Nutrition 27: 96-102.

Ojha BK (2013) Effect of pre-partum strategic supplementation on the performance of buffaloes and calves, Ph.D. Thesis submitted to the IVRI, Izatnagar, India.

Plaizie JCB, Nkya R, Shem MN, Urio NA, McBride BW (1999) Supplementation of dairy cows with nitrogen molasses mineral blocks and molasses urea mix during the dry season. AsianAustralasian Journal of Animal Sciences 12 : 735-741.

Preston TR, Leng RA (1987) Matching ruminant production systems with available resources in the tropics and subtropics. Penambul Books, Armidale, Australia, pp. 135.

Ramesh BK, Thirumalesh T, Suresh BN (2009) Effect of feeding of urea mineral molasses block on milk production, milk composition and onset of estrus in dairy animals. Indian Journal of Animal Nutrition 26:322-26.

Saadullah M, Haque M, Dolberg F (1981) Effectiveness of ammonication through urea in improving the feeding value of rice straw in ruminants. Tropical Animal Health and Production 6:30-36

Sahoo A, Elangovan AV, Mehra UR, Singh UB (2004) Catalytic supplementation of urea-molasses on nutritional performance of male buffalo (Bubalus bubalis) calves. Asian-Australasian Journal of Animal Sciences 17: 621-628.

Singh P, Kishan J (1994) Effect of mode of urea supplementation on nutrient utilization from straw based diet by buffalo calves. Indian Journal of Animal Nutrition 64: 163-166.

Wanapat M, Petlum A, Pimpa O (1999) Strategic supplementation with a high quality feed block on roughage, milk yield and composition and economic return in lactating dairy cows. AsianAustralasian Journal of Animal Sciences 12 : 901-903. 